\title{
Effect of the Structure of the meso-Alkyl Substituent on the Physicochemical and Coordination Properties of the Porphyrin Ligand
}

\author{
S. A. Syrbu, ${ }^{a} @$ S. G. Pukhovskaya, ${ }^{\text {b }}$ Dao The Nam, ${ }^{c}$ Yu. B. Ivanova, ${ }^{a}$ \\ and M. I. Razumov ${ }^{\mathrm{d}}$ \\ ${ }^{a}$ G.A. Krestov Institute of Solutions Chemistry of Russian Academy of Science Russia, 153045 Ivanovo, Russia \\ 'Ivanovo State University of Chemistry and Technology, 153000 Ivanovo, Russia \\ 'Institute of Material Chemistry, Vietnam Academy of Military Science and Technology, Hanoi, Vietnam \\ ${ }^{\mathrm{d}}$ N.S. Kurnakov Institute of General and Inorganic Chemistry, Russian Academy of Sciences, 117907 Moscow, Russia \\ ${ }^{\circledR}$ Corresponding author E-mail: sasyrbu@gmail.com
}

\begin{abstract}
The acid-base and coordination properties for the series of meso-alkyl substituted porphyrins were studied spectrophotometrically: 5,10,15,20-tetrabutylporphyrin $\left(\mathrm{H}_{2}(\mathrm{n} \text { - } \mathrm{Bu})_{4} \mathrm{P}\right)$, 5,10,15,20-tetra-iso-butylporphyrin ( $\mathrm{H}_{2}(\mathrm{i}$ $\left.B u)_{4} P\right)$, 5,10,15,20-tetrakis(tert-butyl)porphyrin $\left(H_{2}(t-B u P)\right.$ ), 5, 10,15,20-tetra(trifluoromethyl)porphine $\left(H_{2}\left(C F_{3}\right){ }_{4} P\right)$. The electronic absorption spectra of molecular and ionized forms of meso-substituted porphyrins in acetonitrile, acid constants and basic ionization of the porphyrins were measured. It is shown that a change in the structure of the mesosubstituent in the porphyrin macrocycle drastically changes the acid-base and coordination properties of the porphyrin. The analysis of complex formation of the molecular and dianionic forms of the porphyrin with zinc acetate has been made.
\end{abstract}

Keywords: Porphyrins, acid-base properties, protonated forms, coordination properties.

\section{Влияние структуры мезо-алкильного заместителя на физико-химические и координационные свойства порфиринового лиганда}

\author{
С. А. Сырбу, ${ }^{\text {a@ }}$ С. Г. Пуховская, ${ }^{\mathrm{b}}$ Аао Тхе Нам, ${ }^{\mathrm{c}}$ Ю. Б. Иванова, ${ }^{\mathrm{a}}$ М. И. Разумов ${ }^{\mathrm{d}}$ \\ ${ }^{\mathrm{a}}$ Институт химии растворов им. Г.А. Крестова Российской академии наук, 153045 Иваново, Россия \\ ${ }^{\mathrm{b}}$ Ивановский государственный химико-технологический университет, 153000 Иваново, Россия \\ ${ }^{\mathrm{c}}$ Институт химии материалов, Вьетнамская академия военных наук и технологий, Ханой, Вьетнам \\ ${ }^{\mathrm{d}}$ Институт общей и неорганической химии им. Н.С. Курнакова РАН, 117907 Москва, Россия \\ ${ }^{\circledR}$ E-mail: sasyrbu@gmail.com
}

\begin{abstract}
Кислотно-основные и координаџионные свойства семейства мезо-алкилзамещенных порфиринов были изучены спектрофотометрически: 5,10,15,20-тетрабутилпорфирин ( $\left.\mathrm{H}_{2}(\mathrm{n}-\mathrm{Bu}){ }_{4} \mathrm{P}\right)$, 5, 10,15,20-тетра-изобутилпорфирин $\left(\mathrm{H}_{2}(\mathrm{i}-\mathrm{Bu})_{4} \mathrm{P}\right), 5,10,15,20$-тетракис (трет-бутил)порфирин $\left(\mathrm{H}_{2}(\mathrm{t}-\mathrm{Bu}){ }_{4} \mathrm{P}\right), 5,10,15,20$-тетра (трифторметил) порфин $\left(\mathrm{H}_{2}\left(\mathrm{CF}_{3}\right)_{4} \mathrm{P}\right)$. Измерены электронные спектры поглощения молекулярных и ионизированных форм мезозамещеннных порфиринов в ацетонитриле, определены константы кислотной и основной ионизации порфиринов. Показано, что изменение структуры заместителя в мезо-положении макрочикла порфирина резко меняет кислотно-основные и координационные свойства порфирина. Проведен анализ комплексообразующих свойств молекулярных и дианионных форм порфириновых лигандов с ацетатом ичнка.
\end{abstract}

Ключевые слова: Порфирины, кислотно-основные свойства, протонированные формы, координационные свойства. 


\section{Introduction}

Porphyrins are naturally occurring aromatic compounds of significant biological role. For example, heme or chlorophyll are indispensable parts of biosystems. The advantage of using porphyrin macrocycles is their conformational flexibility making them able to form multiple nonplanar conformations needed for a variety of biological functions. ${ }^{[1,2]}$ Porphyrins and their metal complexes are used in catalysis, ${ }^{[3-5]}$ dye-sensitized solar cells, ${ }^{[6-8]}$ photodynamic therapy, ${ }^{[9-11]}$ molecular sensors, ${ }^{[12-14]}$ nonlinear optical elements, ${ }^{[15-17]}$ and sorbents ${ }^{[18-19]}$ due to their outstanding properties. Another explanation of unique porphyrin properties originates from the possibility of modification the periphery and the center of the macrocycle by introducing various substituents. A study of substitution effects allows to get closer to solving one of the fundamental problems of chemistry, namely, the relationship between structure and properties of molecules. A variety of practically useful properties of porphyrins and their analogues is also due to the peculiarities of the structure. ${ }^{[20-28]}$ Porphyrins form stable coordination compounds of 1:1 composition (metal:ligand) with most metals (except alkali ones). However, a complexation proceeds as a multicenter interaction and the experimentally derived reaction mechanism has been proposed. ${ }^{[1]}$ The reaction costs a lot of energy needed to overcome the potential barrier. It explains why the porphyrins being kinetically inert, able to form complexes in such conditions as solvation of $\mathrm{NH}$ protons and presence of solvent molecules bound in labile way within coordination sphere of metal cations. A formation of metalloporphyrins, as a rule, proceeds rather slowly, being several orders of magnitude slower than with metal ion complexation with other organic and inorganic ligands..$^{[1,2]}$

Typical spectra of porphyrins and their complexes are characterized by intense absorption in the range from 400 to $500 \mathrm{~nm}$ (Soret band) of molar absorption coefficients reaching up to $200000 \mathrm{~L} /(\mathrm{mol} \cdot \mathrm{cm}){ }^{[2]}$ Such characteristic let us to control the process of complexation by conventional methods of chemical kinetics, for example, by spectrophotometrics.

Until recently, the influence of porphyrin structure on a metal ion complexation was expected to be negligible. One could find reasons for that, for example, a coordination of the $\mathrm{Cu}^{2+}$ ion by porphyrins upon varying functional substituents of porphyrin macrocycle differs in the rate constant of complex formation not larger than for two orders of magnitude. ${ }^{[1]}$ However, later studies demonstrated that introduction of specific substituents may change drastically the geometric parameters of the molecule and selectively regulate desired physico-chemical properties. ${ }^{[24,29-31]}$ These findings are relevant for the studies of influence of electronic and steric effects of the porphyrin macrocycle substituents on the coordination, acid-base, and spectral properties of porphyrins.

In this study, the interrelation was studied between the electronic and structural effects of the substituents at mesopositions of the porphyrin macrocycle on physico-chemical properties and coordinating ability of the following tetrameso-alkyl substituted porphyrins: 5,10,15,20-tetrabutylporphyrin $\left(\mathbf{I}, \mathrm{H}_{2}(n-\mathrm{Bu})_{4} \mathrm{P}\right), 5,10,15,20$-tetra-iso-butylporphyrin (II, $\left.\quad \mathrm{H}_{2}(i-\mathrm{Bu})_{4} \mathrm{P}\right), \quad 5,10,15,20$-tetrakis(tert-butyl)porphyrin
(III, $\left.\mathrm{H}_{2}(t \text {-BuP })_{4}\right), 5,10,15,20$-tetra(trifluoromethyl)porphine $\left(\right.$ IV, $\left.\mathrm{H}_{2}\left(\mathrm{CF}_{3}\right)_{4} \mathrm{P}\right)$.

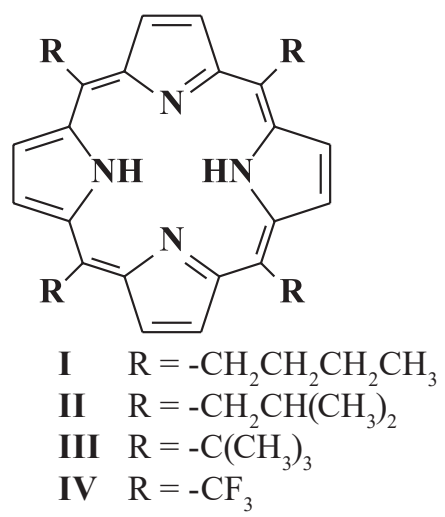

\section{Experimental}

\section{General}

\section{Materials and Reagents}

The porphyrins were synthesized and isolated by known procedures. ${ }^{[32-36]}$ Spectral characteristics of porphyrins I-IV are in agreement with the literature.

5,10,15,20-Tetrabutylporphyrin (I, $\left.H_{2}(n-B u)_{4} P\right)$. UV-Vis $\left(\mathrm{CH}_{2} \mathrm{Cl}_{2}\right) \lambda_{\text {max }}$ (lge) nm: 417 (5.66), 520 (4.18), 555 (4.0), 600 (3.60), 659 (3.90). ${ }^{1} \mathrm{H}$ NMR $\left(\mathrm{CDCl}_{3}\right) \delta_{\mathrm{H}} \mathrm{ppm}: 9.46(\mathrm{~s}, 8 \mathrm{H}, \mathrm{pyr}), 4.93(\mathrm{t}, 8 \mathrm{H}$, $\left.\alpha-\mathrm{CH}_{2}\right), 2.50\left(\mathrm{~m}, 8 \mathrm{H}, \beta-\mathrm{CH}_{2}\right), 1.83\left(\mathrm{~m}, 8 \mathrm{H}, \gamma-\mathrm{CH}_{2}\right), 1.13(\mathrm{t}, 12 \mathrm{H}$, $\left.\mathrm{CH}_{3}\right),-2.64$ (s, 2H, NH).

5,10,15,20-Tetra-iso-butylporphyrin (II, $\left.\mathrm{H}_{2}(\mathrm{i}-\mathrm{Bu})_{4} P\right)$. UV-Vis $\left(\mathrm{CH}_{2} \mathrm{Cl}_{2}\right) \lambda_{\text {max }}$ (lge) nm: 417 (5.65), 519 (4.15), 553 (4.04), 598 (3.7), 658 (3.95). ${ }^{1} \mathrm{H}$ NMR $\delta_{\mathrm{H}} \mathrm{ppm}:-2.65$ (br, s, $\left.2 \mathrm{H}, \mathrm{NH}\right), 1.19$ (d, 24H, $\left.\mathrm{CH}_{3}\right), 2.62-2.81(\mathrm{~m}, 4 \mathrm{H}, \mathrm{CH}), 4.86\left(\mathrm{~d}, 8 \mathrm{H}, \mathrm{CH}_{2}\right), 9.45$ (s, 8H, $\left.\beta-\mathrm{H}\right)$. 5,10,15,20-Tetrakis(tert-butyl)porphyrin (III, $\left.H_{2}\left(t-B u_{4}\right) P\right)$. UV-Vis $\left(\mathrm{CH}_{2} \mathrm{Cl}_{2}\right) \lambda_{\max }(\lg \varepsilon) \mathrm{nm}: 446$ (5.27), 552 (3.85), 596 (3.60), 628 (3.48), 691 (3.30). ${ }^{1} \mathrm{H}$ NMR (250 MHz, $\left.\mathrm{CDCl}_{3}, \mathrm{TMS}\right) \delta_{\mathrm{H}} \mathrm{ppm}$ : 1.52 (br s, $2 \mathrm{H}, \mathrm{NH}), 2.01$ (s, 36H, $\left.\mathrm{CH}_{3}\right), 9.08$ (s, $\left.8 \mathrm{H}, \beta-\mathrm{H}\right)$.

5,10,15,20-Tetra(trifluoromethyl)porphine (IV, $\left.\mathrm{H}_{2}\left(\mathrm{CF}_{3}\right)_{4} \mathrm{P}\right)$. UV-Vis $\left(\mathrm{CH}_{2} \mathrm{Cl}_{2}\right) \lambda_{\text {(g) }}$ (lge) nm: 403 (5.08), 510 (3.97), 545 (3.97), 593 (3.67), 649 (4.00). ' ${ }^{\max } \mathrm{NMR} \delta_{\mathrm{H}} \mathrm{ppm}: 9.60$ (s, $\left.8 \mathrm{H}\right),-2.08$ (s, 2H, NH).

Zinc acetate of analytical grade was recrystallized from aqueous acetic acid and dehydrated at 380-390 K according to. ${ }^{[37]}$ Dry acetonitrile (water contaminant is not higher than $0.03 \%$ ) was used for titration experiment. The 1,8-diazabicyclo[5,4,0]undec7 -en (DBU) was used as deprotonating agent. DBU and perchloric acid $\mathrm{HClO}_{4}$ were used as received without additional purification.

\section{General Experimental Methods and Instrumentation}

${ }^{1} \mathrm{H}$ NMR spectra were recorded with spectrometer Bruker-500 (Germany) using operating frequency of $500 \mathrm{MHz}$ in $\mathrm{CDCl}_{3}$ with TMS as the internal reference. UV-Vis spectra were recorded in the acetonitrile solutions with two-beam spectrophotometers Shimadzu UV-180 and Hitachi U-2000 utilizing a quartz cell of optical path of $1 \mathrm{~mm}$ and $10 \mathrm{~mm}$.

Complexation was studied by spectrophotometric method utilizing thermostatic cuvettes at temperatures from 293 to $308 \mathrm{~K}$. Temperature fluctuations was not higher than $\pm 0.1 \mathrm{~K}$. All studied systems demonstrated isosbestic points in the spectra in course of titration. Reactions obeyed the first order law on porphyrin, which is proved by linearity of $\lg \left(C_{\mathrm{H}_{2 \mathrm{P}}}^{0} / C_{\mathrm{H} 2 \mathrm{P}}\right)-\tau(s)$ dependence $\left(C_{\mathrm{H} 2 \mathrm{P}}^{0}\right.$ and $C_{\mathrm{H} 2 \mathrm{P}}$ are the initial and current concentrations of the porphyrin, respectively). Concentration of the porphyrin during the experiment was controlled by changing the optical density of the solution. 
The linearity of dependence of the optical density of the porphyrin solutions on concentration has been confirmed in previous study. ${ }^{[1]}$

Kinetic experiments were performed under conditions of $\sim 50-100$-fold excess of $\mathrm{Zn}(\mathrm{OAc})_{2}$ over a porphyrin that allows calculating the effective rate constants $\left(k_{\text {eff }}\right)$ of the complex formation reaction by Equation (1):

$$
k_{\mathrm{eff}}=(1 / t) \ln \left[\left(A_{\mathrm{o}}-A_{\infty}\right) /\left(A-A_{\infty}\right)\right]
$$

Here $A_{0}, A, A_{\infty}$ are the optical densities of the porphyrin solution at the initial moment, at the time $t$ and at the end of the reaction, respectively. The optical density of the solutions was measured for each porphyrin at two wavelengths corresponding to the absorption maxima of the porphyrin and its $\mathrm{Zn}$-complex. The root-mean-square error in the determination of $k_{\text {eff }}$ does not exceed $3 \%$. The rate constants of $(n+1)$ order were calculated by Equation (2)

$$
k_{\mathrm{n}+1}=k_{\mathrm{eff}} / C_{\mathrm{Zn}(\mathrm{OAc})_{2}}^{\mathrm{n}},
$$

where $n$ is the order of reaction (2) on zinc acetate being equal to 1.0 in acetonitrile. ${ }^{[38]}$

The activation energy $\left(E_{q}\right)$ for studied temperature range was calculated according to the Arrhenius equation:

$$
E_{a}=19.1 \cdot\left[\left(T_{1} \cdot T_{2}\right) /\left(T_{2}-T_{1}\right)\right] \lg \left(k_{\mathrm{eff} 2} / k_{\mathrm{eff} 1}\right),
$$

where $k_{\text {eff2, }} k_{\text {effl } 1}$ are the effective reaction rate constants at $T_{2}$ and $T_{1}$, respectively. The entropy of transition state formation $\left(\Delta S^{f}\right)$ was calculated by the equation:

$$
\Delta S^{\neq}=19.1 \cdot \lg k_{v}+E_{a} / T-253
$$

Spectrophotometric titration of studied porphyrins with perchloric acid and 1,8-diazabicyclo[5.4.0]undec-7-ene in acetonitrile was performed by means of Shimadzu UV-1800 spectrophotometer. Experimental techniques and processing of experimental data were described previously in detail. ${ }^{[39,40]}$ The error in determining the basicity constants was no higher than $3-5 \%$. Acetonitrile was used as a solvent for titration. The initial compounds in acetonitrile were in a molecular form that is was confirmed by the measured absorption spectra of the porphyrins.

\section{Results and Discussion}

\section{UV-Vis Spectra and Structure of Porphyrins}

Spectra of studied porphyrins (Table 1) revealed that substitution of the electron-donating alkyl groups at mesopositions of the macrocycle (porphyrin I-II) with electronwithdrawing trifluoromethyl groups (porphyrin IV) led to the shift of the absorption bands for about $6-10 \mathrm{~nm}$ into shortwave region. Such hypsochromic shift is due to decreasing in energy of HOMOs. The decrease is explained by lowering of the electron density on the carbon atoms of the methine groups. The phenomenon is in agreement with the Gouterman four-orbital model. ${ }^{[41]}$

However, the introduction of electron-donating tert-butyl groups (III) into the meso-position drastically changes the spectra: despite mentioned above electrondonating effect, a bathochromic shift of all the absorption bands for $\sim 30 \mathrm{~nm}$ is observed (Table 1). According to the literature $^{[33,42-45]}$ and computer modelling data (B3LYP/6311G) (Figure 1) all studied porphyrins have "ruf" type of macrocycle nonplanar deformation.

The structure of both 5,10,15,20-tetrabutylporphyrin and 5,10,15,20-tetra(trifluoromethyl)porphine remains nearly planar (maximum deviation among 24 atoms from the planarity of the macrocycle is $0.08 \AA$ and $0.17 \AA$, respectively). Such structural changes are known to indirectly affect the electronic structure of the macrocycle, namely reducing its aromaticity and increasing the electron density on the central nitrogen atoms. Thus, both the base and acid properties of the molecule increase. ${ }^{[46-48]}$

\section{Formation of the Ionized Porphyrin Species}

The acid-base properties of porphyrins I-IV were studied by spectrophotometric titration at various $\mathrm{p} H$ values of the solution. Depending on the acidity of the medium and the type of the tetrapyrrolic molecule one can obtain both

\begin{tabular}{|c|c|c|c|c|c|c|c|}
\hline Porphyrin & $\lambda(\lg \varepsilon)$ Soret & $\lambda_{4}(\lg \varepsilon)$ & $\lambda_{3}(\lg \varepsilon)$ & $\lambda_{2}(\lg \varepsilon)$ & $\lambda_{1}(\lg \varepsilon)$ & $\mathrm{p} K_{b l, 2}$ & $\mathrm{p} K_{a l, 2}$ \\
\hline IFB & 409 (4.85) & $516(3.84)$ & $550(3.69)$ & $597(3.41)$ & $656(3.54)$ & 24.06 & - \\
\hline IMP & $413(4.83)$ & - & - & $587(3.64)$ & $634(3.63)$ & & \\
\hline IDP & $415(4.84)$ & - & $580(3.65)$ & - & $627(3.92)$ & & \\
\hline IIFB & $410(5.04)$ & $517(4.02)$ & $550(3.88)$ & $597(3.57)$ & $655(3.72)$ & 18.41 & - \\
\hline IIMP & $414(5.00)$ & $473(3.47)$ & - & $590(3.77)$ & $637(3.80)$ & & \\
\hline IIDP & $418(5.04)$ & $470(3.49)$ & $583(3.76)$ & - & $630(4.03)$ & & \\
\hline IIIFB & $446(5.27)$ & $552(3.85)$ & $596(3.60)$ & $628(3.48)$ & $692(3.30)$ & - & -9.75 \\
\hline IIIDD & 444 (5.24) & & $545(3.50)$ & & & & \\
\hline IVFB & $400(5.23)$ & $509(4.14)$ & $544(4.13)$ & $591(3.84)$ & $647(4.11)$ & 3.33 & -9.69 \\
\hline IVMP & $415(5.24)$ & $511(3.74)$ & $547(4.01)$ & $589(4.08)$ & $645(3.80)$ & & \\
\hline IVDP & 417 (5.55) & $570(4.22)$ & - & $614(4.13)$ & - & & \\
\hline IVDD - & $431(4.96)$ & & & $598(4.00)$ & $717(3.89)$ & & \\
\hline
\end{tabular}

Table 1. Wavelength, maxima and extinction coefficients of UV-Vis absorption spectra of molecular (FB) and ionized (monoprotonated (MP), doubly protonated (DP) and doubly deprotonated (DD)) forms of meso-substituted porphyrins in acetonitrile, indicators of acid and basic ionization of porphyrins (I-IV). 
single- and doubly-charged ions being in equilibrium with each other and neutral form.

$$
\begin{aligned}
& \mathrm{H}_{3} \mathrm{P}^{+} \stackrel{K_{b 1}}{\rightleftarrows} \mathrm{H}_{2} \mathrm{P}+\mathrm{H}^{+}, \\
& \mathrm{H}_{4} \mathrm{P}^{2+} \stackrel{K_{b 2}}{\rightleftarrows} \mathrm{H}_{3} \mathrm{P}^{+}+\mathrm{H}^{+}, \\
& \mathrm{H}_{2} \mathrm{P} \stackrel{K_{a 1}}{\rightleftarrows} \mathrm{HP}^{-}+\mathrm{H}^{+}, \\
& \mathrm{HP}^{-} \stackrel{K_{a 2}}{\rightleftarrows} \mathrm{P}^{2-}+\mathrm{H}^{+},
\end{aligned}
$$

where $\mathrm{H}_{2} \mathrm{P}, \mathrm{HP}^{-}, \mathrm{P}^{2-}, \mathrm{H}_{3} \mathrm{P}^{+}, \mathrm{H}_{4} \mathrm{P}^{2+}$ are the molecular, monoand double-deprotonated and protonated forms of the porphyrins. The dissociation constants of protonated forms of porphyrins and the state of dissociation of molecular forms are traditionally designated as $K_{\mathrm{b}}$ and $K_{\mathrm{a}}{ }^{[48-50]}$

The dissociation of cationic type proceeding within acidic medium was studied in acetonitrile (AN)-perchloric acid ( $0.01 \mathrm{M}$ solution in acetonitrile) system at $298 \mathrm{~K}$. Under these conditions $\mathrm{HClO}_{4}$ having high dissociation constant ${ }^{[49]}$ is completely dissociated and the protonation process is due to solvated protons. Equilibria taking place in the solution are described by Equations 5 and 6. The overall constant of the first and second steps ionization for studied compounds determined with the $\mathrm{AN}-\mathrm{HClO}_{4}$ system at $298 \mathrm{~K}$ was calculated by Equation (9):
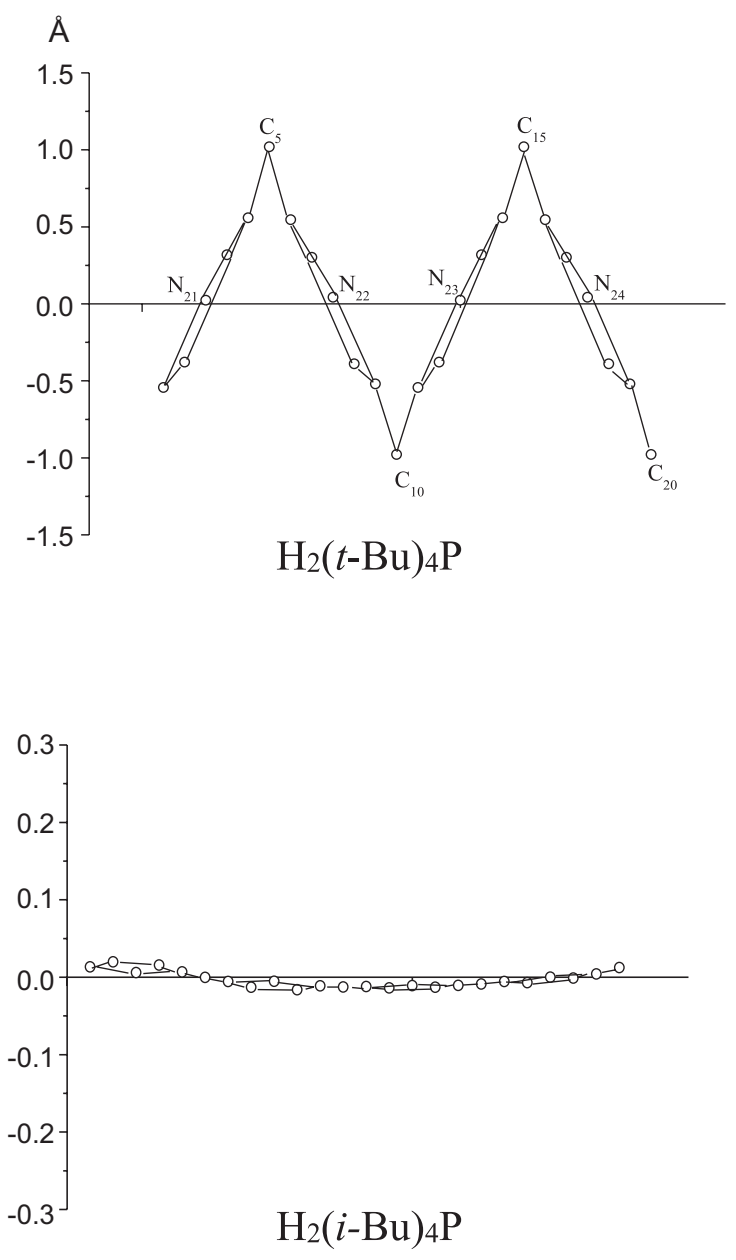

$$
\mathrm{p} K_{b}=\mathrm{p} H+\lg I n d,
$$

where $K_{b}$ is the constant of the compound basicity, Ind is the indicator ratio $\left[\mathrm{H}_{4} \mathrm{P}^{2+}\right] /\left[\mathrm{H}_{3} \mathrm{P}^{+}\right], \mathrm{pH}$ is the analytical value of the acidity of the solution contributed by the titrant.

The spectral features of the molecular and protonated forms, as well as the total constants of the first and second steps ionization for studied compounds in the $\mathrm{AN}-\mathrm{HClO}_{4}$ system at $298 \mathrm{~K}$ are presented in Table 1. Typical spectral changes during the titration are shown in Figures 2 and 3.

Substitution of trifluoromethyl groups ((I-) effect) with alkyl substituents in the meso-positions of the porphyrin macrocycle $((\mathrm{I}+)$ effect) leads to an increase in electron density on the central nitrogen atoms and, as a result, the basicity constant $\left(-\lg K_{b l, 2}\right)$ increase for about 20 orders of magnitude. The porphyrins form the following series:

$$
\text { IV }(3.33)<<\mathbf{H}_{\mathbf{2}} \mathbf{P}\left(15.35^{[50]}\right)<\text { II }(18.41)<\text { I }(24.06)
$$

The decrease in the basicity of 5,10,15,20-tetra-isobutylporphyrin compared to 5,10,15,20-tetrabutylporphyrin $\mathrm{H}_{2}(n-\mathrm{Bu})_{4} \mathrm{P}$ is apparently caused by steric factors providing slightly higher deformation of the macrocycle. Spectrophotometric titration of the $\mathrm{H}_{2}(t-\mathrm{Bu})_{4} \mathrm{P}$ was failed to fix stable protonated forms of the compound. It is likely to be due to the extreme deformation of the macrocycle and instability
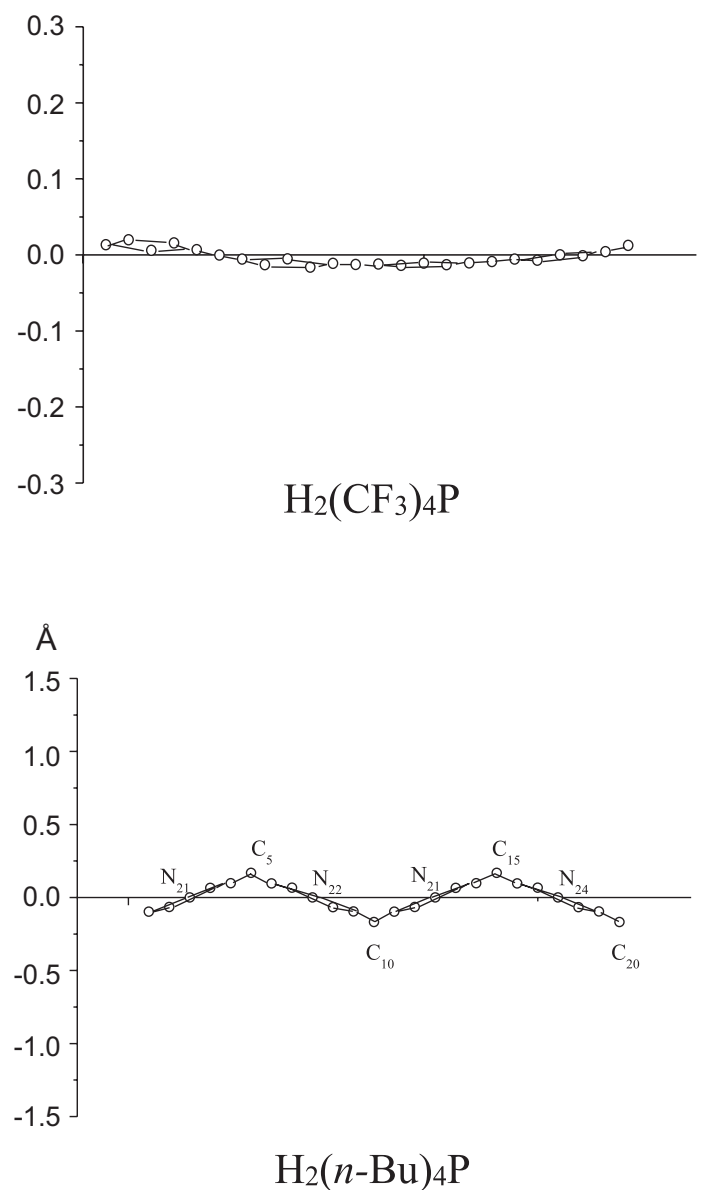

Figure 1. The deviation of the atoms from the mean planes of the macrocycle carried out through 24 atoms of the porphyrin macrocycle according to the calculations by the B3LYP/6-311G method. 


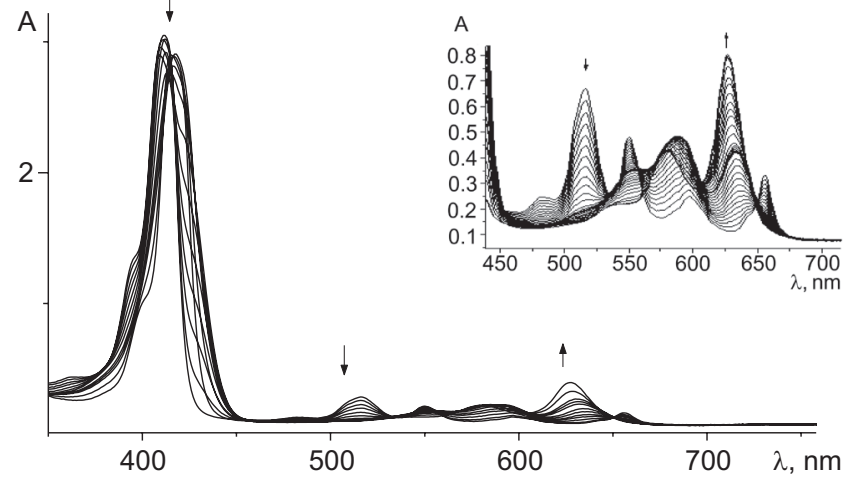

(A)

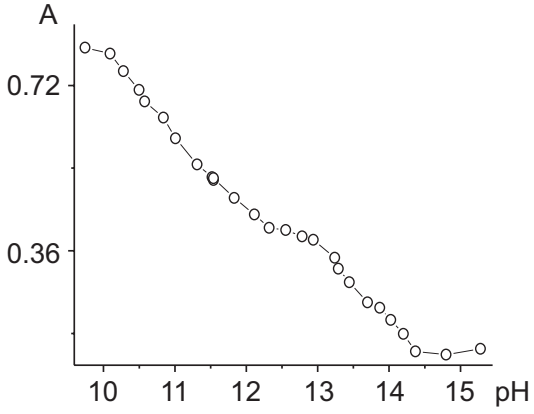

(B)

Figure 2. UV-Vis spectra (A) and the spectrophotometric titration curve $(\lambda=627 \mathrm{~nm})(\mathrm{B})$ of compound $\mathbf{I}$ in the $\mathrm{AN}-\mathrm{HClO}_{4}$ system, $\left(C_{\text {porp }}\right.$ $\left.=1.71 \cdot 10^{-5} \mathrm{~mol} \cdot \mathrm{L}^{-1} ; C_{\mathrm{HClO} 4}=0 \div 3.40 \cdot 10^{-5} \mathrm{~mol} \cdot \mathrm{L}^{-1}\right), 298 \mathrm{~K}$.

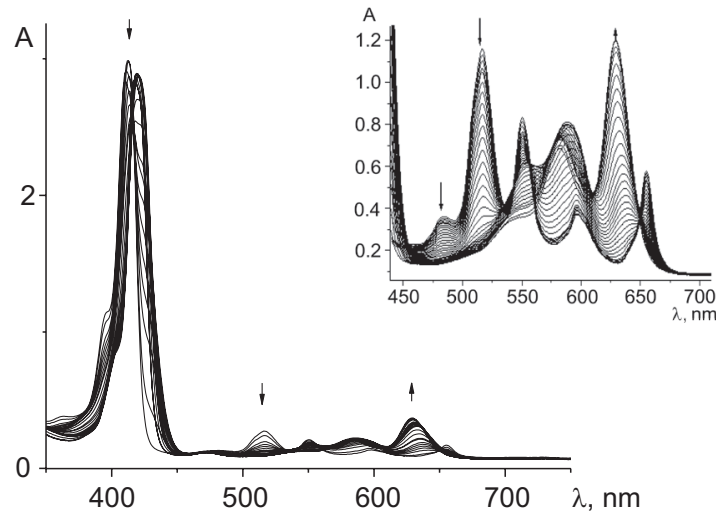

(A)

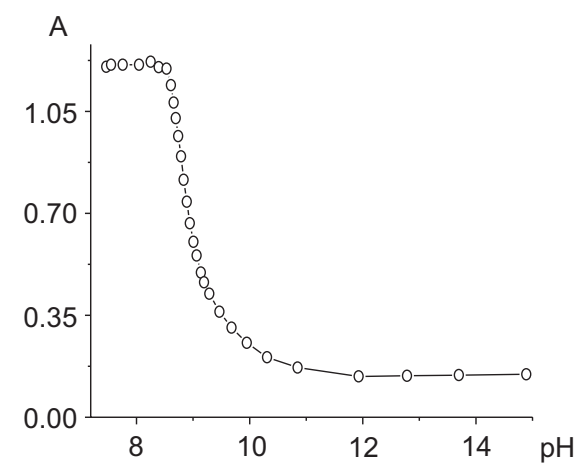

(B)

Figure 3. UV-Vis spectra (A) and the spectrophotometric titration curve $(\lambda=629 \mathrm{~nm})(\mathrm{B})$ of compound $\mathbf{I I}$ in the $\mathrm{AN}-\mathrm{HClO}_{4}$ system, $\left(C_{\text {porp }}\right.$ $\left.=1.4 \cdot 10^{-5} \mathrm{~mol} \cdot \mathrm{L}^{-1} ; C_{\mathrm{HClO} 4}=0 \div 3.3 \cdot 10^{-5} \mathrm{~mol} \cdot \mathrm{L}^{-1}\right), 298 \mathrm{~K}$.

of the protonated forms. However, the authors ${ }^{[42-43]}$ applying more polar methanol as a solvent found protonation to occur along two opposite meso-carbons during the formation of the cationic form. This actually results in the formation of porphodimethene involving $s p^{3}$-hybridized carbon mesoatoms, which relieves the deformation stress, caused by the protonation of the central nitrogen atoms, and contributes to the stabilization of the dicationic form.

An influence of alkyl substituent structure is clear when the acidic properties of the compounds I-IV are obtained. Acid ionization constants were also obtained by spectrophotometric titration in acetonitrile-1,8-diazabicyclo[5.4.0] undec-7-en (DBU) system at $298 \mathrm{~K}$. Anionic forms of the $\mathrm{H}_{2}(i-\mathrm{Bu})_{4} \mathrm{P}, \mathrm{H}_{2}(n-\mathrm{Bu})_{4} \mathrm{P}$ were not obtained even at maximum concentrations of DBU. It indicates very low acidity of studied tetra-meso-alkyl substituted porphyrins. Spectrophotometric titration of the $\mathrm{H}_{2}\left(\mathrm{CF}_{3}\right)_{4} \mathrm{P}$ and $\mathrm{H}_{2}(t-$ $\mathrm{Bu})_{4} \mathrm{P}$ revealed the formation of two families of spectral curves upon increase in DBU concentration, each of them have its own set of isobestic points. This fact indicates two-step deprotonation process. The coordinates of the inflection point (and corresponding $C_{D B U}$ ) determined from the titration curve (the example is shown in the Figure 4) allow distinguishing two ranges within the spectrum of the reaction system corresponding to the first and second deprotonation steps (Equations (7), (8)), i.e. point to the formation of mono- and dianionic types $\left(\mathrm{HP}^{-}, \mathrm{P}^{2-}\right)$ of the $\mathrm{H}_{2}\left(\mathrm{CF}_{3}\right)_{4} \mathrm{P}$ and $\mathrm{H}_{2}(t-\mathrm{Bu})_{4} \mathrm{P}$ porphyrins. The values of the overall acidity constants for the $\mathrm{H}_{2}\left(\mathrm{CF}_{3}\right)_{4} \mathrm{P}$ and $\mathrm{H}_{2}(t-\mathrm{Bu})_{4} \mathrm{P}$ were calculated according to the Equation (10) and are presented in Table 1.

$$
p K_{\mathrm{a}}=\lg \operatorname{Ind}+2 \lg C_{\mathrm{DBU}}
$$

Similar values of the acidity constants for the $\mathrm{H}_{2}\left(\mathrm{CF}_{3}\right)_{4} \mathrm{P}$ and $\mathrm{H}_{2}(t-\mathrm{Bu})_{4} \mathrm{P}$ are due to different origin of the effects of meso-substituents in these two cases. From one side, the pronounced electronic influence of a strong electronaccepting group in the $\mathrm{H}_{2}\left(\mathrm{CF}_{3}\right)_{4} \mathrm{P}$ is observed. On the other, the dominating factor for the $\mathrm{H}_{2}(t-\mathrm{Bu})_{4} \mathrm{P}$ is the deformation of the planar structure resulting from mutual repulsion between $\beta$-pyrrole protons of the macrocycle and protons of the bulky tert-butyl group. A distortion of the macrocycle planarity leads to slightly detaching $\pi$-electron systems 

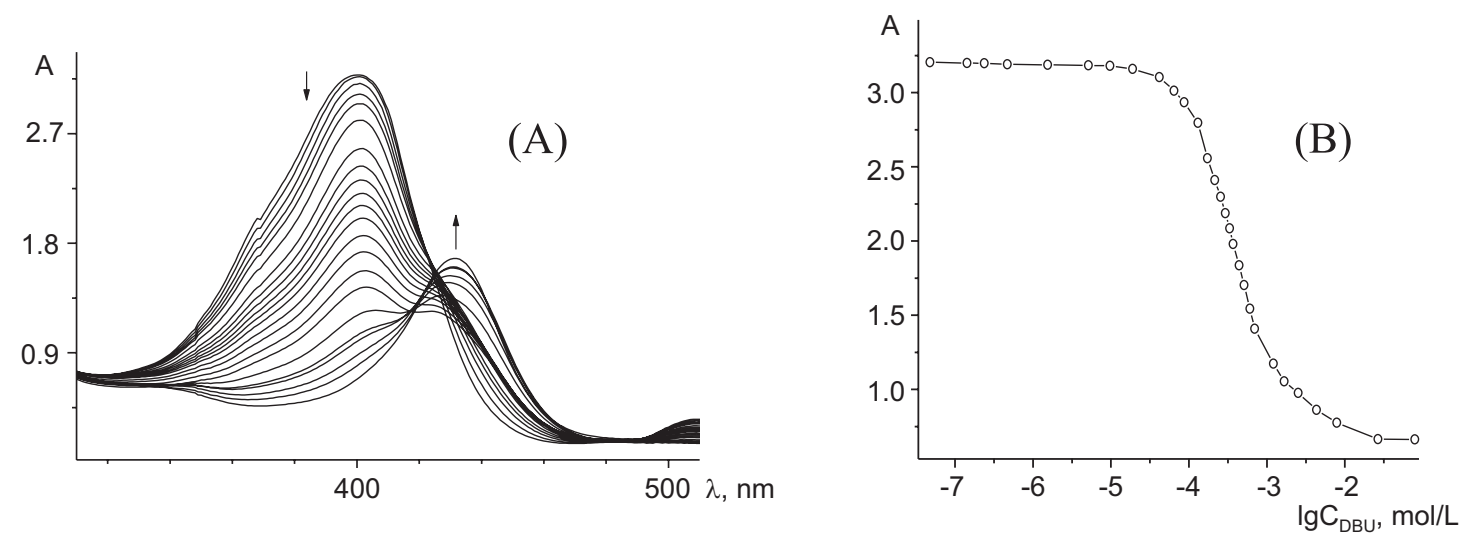

Figure 4. UV-Vis spectra (A) and the spectrophotometric titration curve $(\lambda=400 \mathrm{~nm})(\mathrm{B})$ of compound IV in the $\mathrm{AN}-\mathrm{HClO}_{4}$ system, $\left(C_{\text {porp }}\right.$ $\left.=1.8910^{-5} \mathrm{~mol} \cdot \mathrm{L}^{-1} ; C_{\mathrm{DBU}}=0 \div 7.9 \cdot 10^{-3} \mathrm{~mol} \cdot \mathrm{L}^{-1}\right), 298 \mathrm{~K}$.

of pyrrole and pyrrolenine fragments and, as a result, to an increasing both base and acid properties.

Interestingly, further increase of the organic base concentration (above $3.8 \cdot 10^{-5} \mathrm{M}$ ) completely destroys the $\mathrm{H}_{2}(t-\mathrm{Bu})_{4} \mathrm{P}$ macrocycle. In this way, the concentration range of the organic base (DBU) allowing existence of deprotonated $(t-\mathrm{Bu})_{4} \mathrm{P}^{2-}$ was determined.

\section{Kinetic Studies}

The study of complexation of porphyrins with zinc acetate was carried out by a spectrophotometric method using $\mathrm{AN}$ and in $\mathrm{AN}+\mathrm{DBU}$ systems.

The coordination of the porphyrin ligand with zinc acetate in gioven solvent proceeds according to the Equation (11):

$$
\mathrm{H}_{2} \mathrm{P}+\left[\mathrm{Zn}(\mathrm{OAc})_{2}(\mathrm{AN})_{n-2}\right] \rightarrow \mathrm{ZnP}+2 \mathrm{HOAc}+(n-2) \mathrm{AN}
$$

One can study the formation of zinc complexes within the $\mathrm{AN}+\mathrm{H}_{2} \mathrm{P}+\mathrm{DBU}$ system according to the "ionic mechanism" upon establishing the concentration of an organic base, at which all molecules are double-deprotonated (Figure 5). The reactions can be represented by the Equation:

$$
\begin{aligned}
& {[\mathrm{DBU} \cdot 2 \mathrm{H}]^{2+} \mathrm{P}^{2-}+\left[\mathrm{Zn}(\mathrm{OAc})_{2}(\mathrm{AN})_{n-2}\right] \rightarrow} \\
& \rightarrow \mathrm{ZnP}+2 \mathrm{HOAc}+(n-2) \mathrm{AN}+\mathrm{DBU},
\end{aligned}
$$

where $n$ is the coordination number of zinc cation.

In all the titration experiments the distinct isobestic points in the spectra have been observed. Typical spectral changes for compound IV are shown in Figure 6. The kinetic parameters of $\mathrm{Zn}$ porphyrinates formation reactions are presented in Table 2.

Electron-accepting groups in the meso-positions of the macrocycle are known to reduce an electron density on the tertiary nitrogen atoms not contributing a strengthening of the $\mathrm{N} \rightarrow \mathrm{M}$ bonds of the transition state. As a result, it can slow down the complexation. Electron-donating substituents demonstrate the opposite effect. However, an increase in the rate constant of zinc ion complexation for three orders of magnitude, revealed for the molecular forms upon the transition from the $\mathrm{H}_{2}(t-\mathrm{Bu})_{4} \mathrm{P}$ to $\mathrm{H}_{2}\left(\mathrm{CF}_{3}\right)_{4} \mathrm{P}$, is likely depends

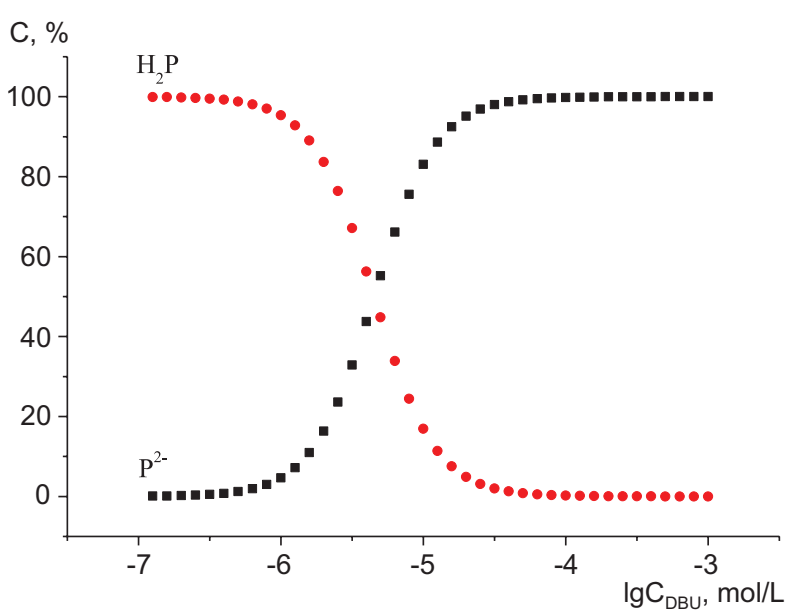

Figure 5. The distribution of the concentrations of molecular and double deprotonated forms of porphyrins during the titration of porphyrin IV.

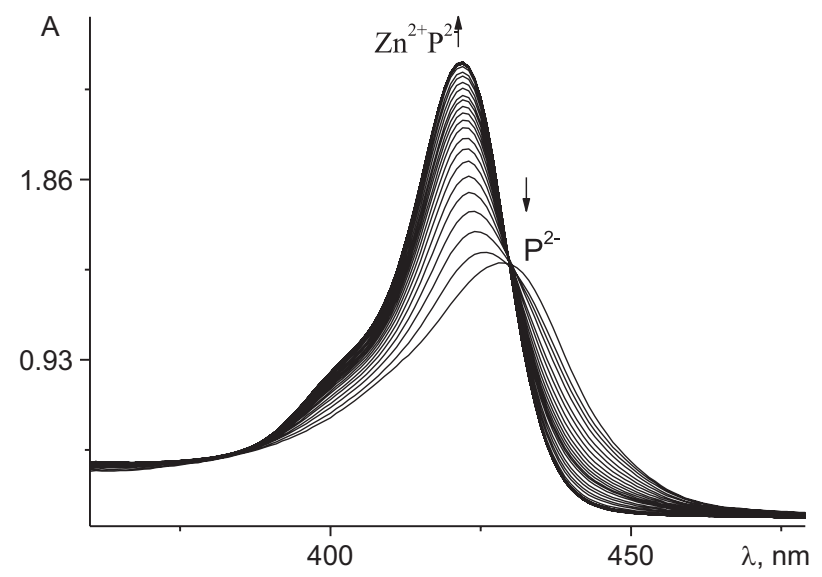

Figure 6. Changes in electronic absorption spectra during the coordination reaction of dianion $\mathbf{I V}$ with zinc acetate in the AN$\mathrm{DBU}-\mathrm{Zn}(\mathrm{OAc})_{2}$ system at $298 \mathrm{~K}, C_{\mathrm{Zn}(\mathrm{OAc})_{2}}=0.3 \cdot 10^{-3} \mathrm{~mol} \cdot \mathrm{L}^{-1}$.

not only on electronic influence of the substituent, but also on an extremely distorted structure of the $\mathrm{H}_{2}(t-\mathrm{Bu})_{4} \mathrm{P}$. 
Table 2. Kinetic parameters of the reaction of the formation of Zn-porphyrins in acetonitrile and an AN-DBU.

\begin{tabular}{cccccc}
\hline Porphyrin & Solvent & $C_{\mathrm{Zn}(\mathrm{OAc})_{2}}, 10^{3} \mathrm{~mol} \cdot \mathrm{L}^{-1}$ & $k_{v}^{298}, 10^{3} \mathrm{~L} \cdot \mathrm{mol} \cdot \mathrm{s}^{-1}$ & $E_{a}, \mathrm{~kJ} \cdot \mathrm{mol}^{-1}$ & $\Delta S^{\ddagger}, \mathrm{J} \cdot \mathrm{mol}^{-1} \cdot \mathrm{K}^{-1}$ \\
\hline $\mathrm{H}_{2}(t-\mathrm{Bu})_{4} \mathrm{P}$ & $\mathrm{AN}$ & 4.5 & $4080 \pm 5$ & $46.4 \pm 0.7$ & $-85.6 \pm 1.5$ \\
$(t-\mathrm{Bu})_{4} \mathrm{P}^{2-}$ & $\mathrm{AN}+\mathrm{DBU}$ & 4.5 & $4620 \pm 5$ & $38.9 \pm 0.5$ & $-109.9 \pm 2.0$ \\
$\mathrm{H}_{2}\left(\mathrm{CF}_{3}\right)_{4} \mathrm{P}$ & $\mathrm{AN}$ & 11.4 & $6.05 \pm 0.08$ & $52 \pm 2$ & $-175 \pm 2$ \\
$\left(\mathrm{CF}_{3}\right)_{4} \mathrm{P}^{2-}$ & $\mathrm{AN}+\mathrm{DBU}$ & 0.30 & $4006 \pm 5$ & $24 \pm 1$ & $-143 \pm 2$ \\
\hline
\end{tabular}

The distortion is caused by a steric effect of the bulky tertbutyl substituents.

The analysis of the zinc complexes formation in acetonitrile in the presence of DBU revealed that the rate of reaction (12) increases for about three orders by magnitude upon transition from molecular to dianionic forms of the compound IV. The process is accompanied with a $28 \mathrm{~kJ} \cdot \mathrm{mol}^{-1}$ decrease in the reaction activation energy. This fact can be explained by the lack of energy needed for the deformation and a breaking of central NH bonds, as well as by stronger polarization of the molecule. It results in the higher degree of solvation of anionic porphyrin forms in the transition state $\left(\Delta \mathrm{S}^{\neq}\right.$decreases for about $\left.30 \mathrm{~J} \cdot \mathrm{mol}^{-1} \cdot \mathrm{K}^{-1}\right)$.

Highly-distorted porphyrin exhibits higher basicity and acidity compared to the planar porphyrins. It means that protons in the macrocycle core are weakly bound by the nitrogen atoms and deprotonation does not significantly contribute the energy of the system. In addition, one can state that the structure of the macrocycle III containing nitrogen atoms exposed out of the macrocycle plane favors interaction with the metal solvatocomplex.

\section{Conclusion}

Thus, the introduction of the alkyl substituents with different electronic and steric effects into the meso-position of the porphyrin macrocycle changes the metal ion coordination, acid-base and spectral properties of the porphyrin ligand, as well as leads to the changes in the geometry of the molecule and promotes selective regulation of the physicochemical properties of the compound. The key fundamental problem being solved in the study contributes to the general knowledge of the processes occurring upon interaction of nitrogen-containing macrocycles and metal ions. The disclosure of the mechanism of these processes contributes to the modelling approaches needed for the successful design of complex organic compounds and development of new sensitive and selective sensors based on these compounds.

Acknowledgments. This research was funded by the Russian Science Foundation (project № 19-03-00214 A) and performed with using of equipment of the Shared Facility Centre, the Upper Volga Regional Centre of Physicochemical Studies.

\section{Referenses}

1. Berezin B.D. Coordination Compounds of Porphyrins and Phthalocyanines. New York-Toronto: Wiley, 1981. 286 p.
2. Gurinovich G.P., Sevchenko K.N. Spectroscopy of Chorophyll and Related Compounds. Minsk, 1968. 517 p. (in Russ.) [Гуринович Г.П., Севченко К.Н. Спектроскопия хлорофилла и родственных соединений. Минск: Наука и техника, 1968. 517 с.].

3. Lu H.-J., Jiang H.-L., Wojtas L., Zhang X.P. Angew Chem., Int. Ed. 2010, 49, 10192.

4. Visser S.P., Valentine J.S., Nam W. Angew. Chem., Int. Ed. 2010, 49, 2099.

5. Araghi M., Mirkhani V., Moghadam M., Tangestaninejad S., Mohammdpoo-raltork I. Dalton Trans. 2012, 41, 3087.

6. Yella A., Lee H.-W., Tsao H.N., Yi C., Chandiran A.K., Nazeeruddin Md.K., Diau E.W.-G., Yeh C.-Y., Zakeeruddin S.K., Grätzel M. Science 2011, 334, 629.

7. Subbaiyan N.K., D'Souza F. Chem. Commun. 2012, 48, 3641.

8. Li L.-L., Diau E.W.-G. Chem. Soc. Rev. 2011, 42, 291.

9. Gros C.P., Eggenspiller A., Nonat A., Barbe J.-M., Denat F. Med. Chem. Commun. 2011, 2, 119.

10. Bříza T., Králová J., Cígler P., Kejík Z., Poučková P., Vašek P., Moserová I., Martásek P., Král V. Bioorg. Med. Chem. Lett. 2012, 22, 82 .

11. Kumar D., Mishra B.A., Shekar K.P.C., Kumar A., Akamatsu K., Kusaka E., Ito T. Chem. Commun. 2013, 49, 683.

12. Zhang J., Li Y., Yang W., Lai S.-W., Zhou C., Liu H., Che C.-M., Li Y. Chem. Commun. 2012, 48, 3602.

13. Rakow N.A., Suslick K.S. Nature 2000, 406, 710.

14. Suslick K.S. MRS Bull. 2004, 29, 720.

15. Senge M.O., Fazekas M., Notaras E.G.A., Blau W.J., Zawadzka M., Locos O.B., Mhuircheartaigh E.M.N. $A d v$. Mater. 2007, 19, 2737.

16. Torre G., Vázquez P., Agulle-Lapez F., Torres T. Chem. Rev. 2004, 104, 3723.

17. Zakavi S., Omidyan R., Ebrahimi L., Heidarizadi F. Inorg. Chem. Commun. 2011, 14, 1827.

18. Kosal M.E., Chou J.-H., Wilson S.R., Suslick K.S. Nat. Mater. 2002, $1,118$.

19. Suslick K.S., Bhyrappa P., Chou J.H., Kosal M.E., Nakagaki S., Smithenry D.W., Wilson S.R. Acc. Chem. Res. 2005, 38, 283.

20. The Porphyrin Handbook, Vol. 1 (Kadish K.M., Smith K.M., Guilard R., Eds.) Academic Press, 1999. 405 p.

21. The Porphyrin Handbook, Vol. 6 (Kadish K.M., Smith K.M., Guilard R., Eds.) Academic Press, 2000. 346 p.

22. Ono N., Yamada H., Okujima T. In: Handbook of Porphyrin Science, Vol. 2. Singapore: World Scientific, 2010, p. 102.

23. Vicente M.G.H., Smith K.M. Curr. Org. Synth. 2014, 11, 3.

24. Golubchikov O.A., Pukhovskaya S.G., Kuvshinova E.M. Russ. Chem. Rev. 2005, 74, 249.

25. Vashurin A.S., Pukhovskaya S.G., Voronina A.A., Semeikin A.S., Golubchikov O.A. Macroheterocycles 2012, 5, 72.

26. Senge M.O. Chem. Commun. 2006, 243.

27. Medforth C.J., Muzzi C.M., Smith K.M., Abraham R.J., Hobbs J.D., Shelnutt J.A. J. Chem. Soc. Chem. Commun. 1994, 1843.

28. Retsek J.L., Medforth C.J., Nurco D.J., Gentemann S., Chirvony V.S., Smith K.M., Holten D. J. Phys. Chem. B 2001, 105, 6396. 
Effect of the meso-Alkyl Substituent on the Properties of the Porphyrin

29. Pukhovskaya S.G., Efimovich V.A., Golubchikov O.A. Russ. J. Inorg. Chem. 2013, 58, 406.

30. Dao Tkhe Nam, Ivanova Yu.B., Puhovskaya S.G., Kruk M.M. RSC Adv. 2015, 5, 26125.

31. Dyrda G., Słota R., Broda M.A., Mele G. Res. Chem. Intermed. 2016, 42, 3789.

32. Oulmi D., Maillard P., Guerquin-Kern J.-L., Huel C., Momenteau M. J. Org. Chem. 1995, 60, 1554.

33. Senge M.O., Bischoff I., Nelson N.Y., Smith K.M. J. Porphyrins Phthalocyanines 1999, 3, 99.

34. Gong L-C., Dolphin D. Can. J. Chem. 1985, 401.

35. d'A. Rocha Gonsalves A.M., Varejao J.M.T.B., Pereira M. J. Heterocycl. Chem. 1991, 28, 635.

36. Goll G., Moore K.T., Ghosh A., Therien M.J., J. Am. Chem. Soc. 1996, 118, 8344.

37. Karyakin Yu.V., Angelov I.I. Pure Chemical Reagents. Moscow: Chemistry, 1974. 407 p. (in Russ.) [Карякин Ю.В., Ангелов И.И. Чистые химические вещества. М.: Химия, 1974. 407 с.].

38. Pukhovskaya S., Ivanova Yu., Dao The Nam, Vashurin A., Golubchikov O.A. J. Porphyrins Phthalocyanines 2015, 19, 858.

39. Ivanova Yu.B., Sheinin V.B., Mamardashvili N.Zh. Russ. J. Gen. Chem. 2007, 77, 1458.
40. Ivanova Yu.B., Churakhina Yu.I., Mamardashvili N.Zh. Russ. J. Gen. Chem. 2008, 78, 673.

41. Gouterman M. J. Mol. Spectrosc. 1961, 6, 138.

42. Ema T., Senge M.O., Nelson N.J. Angew. Chem., Int. Ed. 1994, 33, 1879.

43. Senge M.O., Ema T., Smith K.M. J. Chem. Soc. Chem. Commun. 1995, 733 .

44. Fu-Quan Bai, Naoki N., Akira N., Hasegawa J. J. Phys. Chem. A 2014, 118, 4184.

45. Haddard R.E., Gazeau S., Pecaut J. J. Am. Chem. Soc. 2003, 125, 1253.

46. Berezin D.B., Ivanova Yu.B., Sheinin V.B. Russ. J. Phys. Chem. 2007, 81, 1986.

47. Pukhovskaya S.G., Dao Tkhe Nam, Ivanova Yu.B., Liulkovich L.S., Semeikin A.S., Syrbu S.A., Kruk M.M. J. Incl. Phenom. Macrocycl. Chem. 2017, 89, 325.

48. Ivanova Yu.B., Pukhovskaya S.G., Mamardashvili N.Zh., Koifman O.I., Kruk M.M. J. Mol. Liq. 2019, 275, 491.

49. Kolthoff L.M., Chantooni M.K., Sadhana Ir. Anal. Chem. 1967, 39, 1627.

50. Andrianov V.G., Malkova O.V. Macroheterocycles 2009, 2, 130. 